\title{
Geographical Distribution of Access to Healthcare in Patients Diagnosed with Hypospadias
}

\section{Distribución geográfica del acceso a la asistencia sanitaria en pacientes con diagnóstico de hipospadias}

\author{
${ }^{1}$ Division of Urology, Seattle Children's Hospital, University of \\ Washington, Seattle, Washington, United Sates \\ 2 Department of Urology, Fundación Santa Fe de Bogota, Universidad \\ de los Andes, Bogotá, Colombia \\ ${ }^{3}$ School of Medicine, Universidad Nacional de Colombia, Bogotá, Colombia \\ ${ }^{4}$ School of Medicine, Universidad de los Andes, Bogotá, Colombia \\ 5 Instituto de Genética Humana, Pontificia Universidad Javeriana, \\ Bogotá, Colombia \\ ${ }^{6}$ Division of Urology, Hospital Universitario San Ignacio, Pontificia \\ Universidad Javeriana, Bogotá, Colombia
}

Nicolas Fernandez ${ }^{1}$ Jessica Santander ${ }^{2}$ Marcela Pérez-Sosa ${ }^{3} \quad$ Alejandro Agudelo ${ }^{4}$

Daniel Sánchez ${ }^{4} \quad$ Nevianni Vélez ${ }^{4}$ Ignacio Zarante ${ }^{5}$ Andres Gutierrez ${ }^{60}$

\author{
Address for correspondence Nicolás Fernández, MD, PhD, Division of \\ Urology, Seattle Childrens Hospital, 4800 Sandpoint Way NE. 98105, \\ Seattle, Washington, United Sates \\ (e-mail: nicolas.fernandez@seattlechildrens.org).
}

Urol Colomb 2021;30(4):e293-e299.

\begin{abstract}
Keywords

- hypospadias

- spatial analysis

- prevalence

Objective Hypospadias is a congenital disease of unknown etiology involving multiple epigenetic, genetic, and endocrinological factors. It is a highly incapacitating condition. Its surgical management is one of the most frequent surgical procedures done by pediatric urologists. Furthermore, the geographical distribution and healthcare access is limited in Colombia. The Colombian Ministry of Health has consolidated a nationwide registry called Integrated Social Protection Information System (SISPRO, in the Spanish acronym) to collect comprehensive information on the use and frequency of resources associated with health care in Colombia. The aim of the present study was to analyze the number of cases reported between 2014 and 2018 and the geographical distribution of access to healthcare of patients with hypospadias in Colombia.

Methods An observational, retrospective study of hypospadias in Colombia, 20142018, was performed using data extracted from the Individual Health Records System (RIPS) in SISPRO. Satscan, version 9.6 was used to perform a distribution analysis of the georeferenced population using a Poisson model. To visualize the results, the software projected the result onto a Google Earth map.

Results Between January 2014 and December 2018, a total of 8,990 cases of hypospadias were evaluated in Colombia. The geographical distribution in the national territory has areas with high evaluation rates. On average, the departments in which the majority of cases were evaluated during the study period were Bogotá, D.C.,
\end{abstract}

received

September 25, 2020

accepted

February 10, 2021
DOI https://doi.org/

$10.1055 / \mathrm{s}-0041-1730359$

ISSN 0120-789X.

e ISSN 2027-0119.
(C) 2021. Sociedad Colombiana de Urología. All rights reserved. This is an open access article published by Thieme under the terms of the Creative Commons Attribution-NonDerivative-NonCommercial-License, permitting copying and reproduction so long as the original work is given appropriate credit. Contents may not be used for commercial purposes, or adapted, remixed, transformed or built upon. (https://creativecommons.org/ licenses/by-nc-nd/4.0/)

Thieme Revinter Publicações Ltda., Rua do Matoso 170, Rio de Janeiro, RJ, CEP 20270-135, Brazil 


\section{Resumen}

Palabras clave

- hipospadias

- análisis espacial

- prevalencia
Antioquia, and Valle del Cauca $(2,196,1,818$ and 1,151 cases, respectively). The statistical analysis of the space exploration ( - Fig. 1) identified the area with the highest concentration of cases (red) and the areas in which the lowest number of patients was evaluated (blue). The geographical distribution showed increasing trends in areas near the center of the country, especially in the cities of Bogotá, Cali, Ibagué, and Pereira. Conclusion There is a greater concentration of cases evaluated in the center of the country, where the cities with better access to subspecialized medical care are located. This highlights inequalities in health services and the opportunity for surgical care among regions of the country. If we consider that the prevalence rates of hypospadias remain stable, $\sim 87 \%$ of the patients with hypospadias will not be evaluated by a subspecialist.

Objetivo Hipospadias es una enfermedad congénita de etiología desconocida que involucra múltiples factores epigenéticos, genéticos y endocrinológicos. Es una condición sumamente incapacitante. Su manejo quirúrgico es uno de los procedimientos quirúrgicos más frecuentes realizados por urólogos pediátricos. Además, la distribución geográfica y el acceso a la atención médica son limitados en Colombia. El Ministerio de Salud de Colombia ha consolidado un registro a nivel nacional denominado Sistema Integrado de Información de Protección Social (SISPRO) para recopilar información integral sobre el uso y frecuencia de los recursos asociados a la atención de la salud en Colombia. El objetivo del presente estudio fue analizar el número de casos notificados entre 2014 y 2018 y la distribución geográfica del acceso a la atención médica por los pacientes con hipospadias en Colombia.

Métodos Se realizó un estudio observacional y retrospectivo de hipospadias en Colombia, 2014-2018, utilizando datos extraídos del Sistema de Registros Sanitarios Individuales (RIPS) en SISPRO. Se usó Satscan, versión 9.6 para realizar un análisis de distribución de la población georreferenciada usando un modelo de Poisson. Para visualizar los resultados, el software proyectó el resultado en un mapa de Google Earth. Resultados Entre enero de 2014 y diciembre de 2018, se evaluaron un total de 8.990 casos de hipospadias en Colombia. La distribución geográfica en el territorio nacional tiene áreas con mayor concentración de la atención de pacientes con hipospadias, al igual que áreas sin atención de esta condicion. En promedio, los departamentos donde se evaluaron la mayoría de los casos durante el período de estudio fueron Bogotá, D.C., Antioquia, y Valle del Cauca (439.2, 363.6, y 230.2, respectivamente). El análisis estadístico de la exploración espacial (-Figura 1) identificó el área con la mayor concentración de casos (rojo) y las áreas donde se evaluó el menor número de pacientes (azul). La distribución geográfica mostró tendencias crecientes en áreas cercanas al centro del país, especialmente en las ciudades de Bogotá, Cali, Ibagué y Pereira.

Conclusiones Existe una mayor concentración de casos evaluados en el centro del país, donde se encuentran las ciudades con un mejor acceso a atención médica subespecializada. Esto pone de relieve las desigualdades en el acceso a los servicios de salud y la oportunidad de atención quirúrgica entre las regiones del país. Si consideramos que las tasas de prevalencia de hipospadias permanecen estables, aproximadamente el $87 \%$ de los pacientes con hipospadias no serán evaluados por un subespecialista. 


\section{Introduction}

Hypospadias is a congenital malformation caused by an abnormal closure of the urethral folds during penile development, giving rise to a urethral opening on the ventral surface of the penis. ${ }^{1-3}$ It is the second most common congenital malformation, after cryptorchidism. ${ }^{1}$ Its prevalence has been described with results such as 20.9 per 10,000 live births worldwide, between 10.6 and 34.7 per 10,000 live births in the European continent, 34.2 per 10,000 live births in North America, and a range between 1.5 and 8.6 per 10,000 live births for Latin American countries. ${ }^{2,4}$ In Colombia, the prevalence of hypospadias has been described to be of 11.3 per 10,000 live births. ${ }^{3,5}$ It is a multifactorial disease, as it has been associated with disruptions in hormonal homeostasis during embryogenesis, multiple environmental factors, and genetic predispositions. ${ }^{6-8}$ The anatomical abnormalities of hypospadias have several long-term consequences on genitourinary function that carry a high Burden of Disease (BoD). ${ }^{9}$ Early surgical intervention has been proven to be necessary for a favorable quality of life and reduction in disability. ${ }^{10,11}$ Hypospadias is a disease with serious and long-lasting psychosocial repercussions. ${ }^{12,13}$ In mid-and low-income countries, access to specialized care is limited. Understanding the geographical distribution of pediatric urology services is needed to improve access and allocate public health resources to improve areas with lack of coverage.

The Colombian Ministry of Health has developed the Integrated Social Protection Information System (SISPRO, in the Spanish acronym). One of the components of SISPRO is the Individual Health Record System (Registro Individual de Prestación de Servicios [RIPS, in the Spanish acronym). The purpose of the RIPS is to centralize health information, facilitating the knowledge of the health or disease status of the population across the regions by time period, insurance regimen, gender and age, among other characteristics. The RIPS is publicly available and is reported on a monthly basis by healthcare providers, health maintenance organizations, and healthcare professionals.

The aim of the present study is to describe the geographical distribution of access to healthcare of patients with hypospadias in Colombia.

\section{Methods}

\section{Data Collection}

For the present observational, retrospective study, data were collected from the RIPS from 2014 to 2018, according to the International Statistical Classification of Diseases and Health Problems 10th revision (ICD-10) related to hypospadias (Q540, Q541, Q542, Q543, Q548, Q549). These diagnoses were scrutinized with two diagnostic filters: confirmed new and confirmed repeated cases, excluding the type of diagnosis, diagnostic impression, and unspecified. To quantify the number of patients with this diagnosis, the function "people attended" was used, which includes each person only once, even if that person has been attended more than once during the previous 5 years.
Analyzed data included all registered male births during the study period in each geographic area, according to vital statistics of births and deaths reported by the National Administrative Department of Statistics (DANE, in the Spanish acronym). For geographical analysis, the geolocation data (latitude and longitude) from each department was extracted from the geoportal of the National Administrative Department of Statistics, using their capital cities as a geographical reference.

To determine the availability of a specialist, we identified all of the members of the Colombian Urological Society. We considered pediatric urologists those who have a dedication of $>70 \%$ of their time to seeing urology pediatric patients.

\section{Statistical Analysis}

The information was recorded in Microsoft Excel for MacOS (Microsoft Corp., Redmond, WA, USA). Satscan v9.6 for MacOS (Satscan) was used to analyze the database, where the georeferenced population distribution values were obtained according to the geographic coordinates. Using a Poisson model, a geographical distribution of hypospadias in Colombia was made. To visualize the results obtained, the software projected the outcome in a Google Earth map.

\section{Results}

Between January 2014 and December 2018, a total of 8,990 cases ("people attended") of hypospadias were assessed in the Colombian territory. - Table 1 shows the number of cases seen per year, in each department. The geographical distribution in the national territory has areas with high evaluation rates. On average, the departments where most cases were evaluated during the study period were Bogotá, D.C., Antioquia and Valle del Cauca (2,196, 1,818 and 1,151 cases, respectively).

Spatial scan statistical analysis identified a total of three clusters, as shown in - Figure 1. The area with the highest concentration of cases is shown in red. The geographic distribution showed increasing trends in areas close to the center of the country, especially in the municipalities of Bogotá, Cali, Ibagué, and Pereira, which agrees with the area where more specialists are available. Meanwhile, clusters in blue shows those municipalities below the average value of cases of hypospadias assessed for the years between 2014 and 2018. The analysis detected areas in the north region of the country, including Barranquilla, Cartagena, Sincelejo, and Monteria, where the number of children evaluated was lower compared with the center of the country. The same occurs for the area delimited by the second cluster, which encompasses the Amazon and Orinoquia regions.

\section{Discussion}

\section{Main Findings}

The present study provides data about the geographical distribution of the cases of hypospadias seen in Colombia from 2014 to 2018 . These results show that there is a greater concentration of evaluated cases in the center of the country, where major cities are located with possible better access to a 
Table 1 Number of people attended in the Colombian territory between 2014 and 2018

\begin{tabular}{|c|c|c|c|c|c|c|}
\hline & \multicolumn{6}{|c|}{ Hypospadias cases assessment* } \\
\hline & 2014 & 2015 & 2016 & 2017 & 2018 & \\
\hline DEPARTMENT & & & & & & TOTAL \\
\hline Amazonas & 1 & 3 & 0 & 1 & 1 & 6 \\
\hline Antioquia & 326 & 334 & 289 & 382 & 487 & 1818 \\
\hline Arauca & 9 & 6 & 3 & 6 & 10 & 34 \\
\hline $\begin{array}{l}\text { Archipiélago de San Andrés, } \\
\text { Providencia y Santa Catalina }\end{array}$ & 3 & 2 & 1 & 0 & 1 & 7 \\
\hline Atlántico & 232 & 227 & 139 & 173 & 194 & 965 \\
\hline Bogotá, D.C. & 478 & 416 & 379 & 472 & 451 & 2196 \\
\hline Bolívar & 149 & 125 & 76 & 109 & 117 & 576 \\
\hline Boyacá & 53 & 50 & 35 & 38 & 36 & 212 \\
\hline Caldas & 54 & 49 & 52 & 28 & 62 & 245 \\
\hline Caquetá & 17 & 10 & 15 & 15 & 25 & 82 \\
\hline Casanare & 10 & 17 & 13 & 13 & 12 & 65 \\
\hline Cauca & 31 & 38 & 44 & 25 & 32 & 170 \\
\hline Cesar & 118 & 141 & 134 & 159 & 125 & 677 \\
\hline Chocó & 12 & 20 & 17 & 28 & 21 & 98 \\
\hline Córdoba & 94 & 93 & 88 & 81 & 87 & 443 \\
\hline Cundinamarca & 144 & 150 & 150 & 157 & 182 & 783 \\
\hline Guaviare & 2 & 2 & 2 & 0 & 1 & 7 \\
\hline Huila & 55 & 43 & 39 & 49 & 62 & 248 \\
\hline La Guajira & 33 & 31 & 26 & 46 & 56 & 192 \\
\hline Magdalena & 89 & 78 & 47 & 65 & 85 & 364 \\
\hline Meta & 36 & 21 & 22 & 21 & 27 & 127 \\
\hline Nariño & 47 & 54 & 42 & 59 & 57 & 259 \\
\hline Norte de Santander & 54 & 52 & 34 & 54 & 59 & 253 \\
\hline Putumayo & 5 & 6 & 7 & 10 & 6 & 34 \\
\hline Quindio & 29 & 20 & 13 & 21 & 26 & 109 \\
\hline Risaralda & 90 & 75 & 37 & 54 & 67 & 323 \\
\hline Santander & 128 & 144 & 122 & 109 & 156 & 659 \\
\hline Sucre & 88 & 68 & 38 & 45 & 56 & 295 \\
\hline Tolima & 54 & 44 & 36 & 32 & 48 & 214 \\
\hline Valle del Cauca & 233 & 239 & 193 & 225 & 261 & 1151 \\
\hline Vaupés & 3 & 2 & 0 & 0 & 0 & 5 \\
\hline Vichada & 2 & 1 & 0 & 0 & 0 & 3 \\
\hline
\end{tabular}

*Reported as $\mathrm{n}$.

subspecialized medical care. This highlights inequities in access to health services and surgical care opportunity among the different regions of the country. To our knowledge, there are 11 full-time pediatric urologists in Bogotá, 2 in Bucaramanga, and 1 in Cali. This explains why the care of hypospadias patients is concentrated in the center of Colombia, making the access to children from other regions difficult. The concentration of resources is inequitable. Specifically for hypospadias, there should be a national system that controls referrals and, probably, a system in which specialized teams go to remote areas and treat these patients may be a cost-effective system. The variety of congenital anomalies in pediatric urology added to the prevalence of these conditions worldwide and the lack of access to trained specialists highlights the critical need to consider pediatric urology as a global surgical health priority. $^{14}$

Taking into account the DANE vital statistics for 2017, congenital abnormalities were among the main causes of mortality in children $<1$ year old, causing $23.4 \%$ of the 


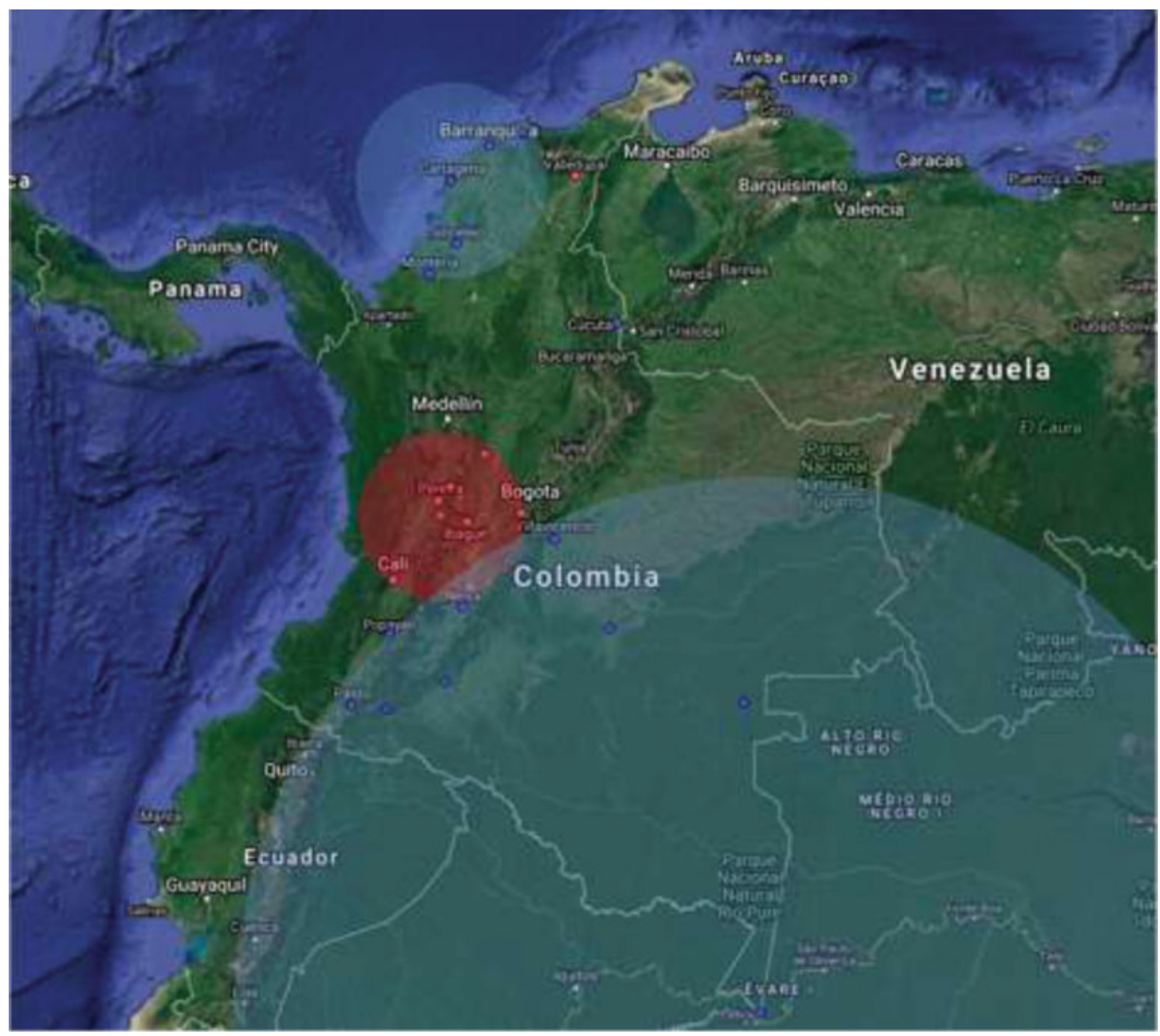

Fig. 1 Spatial-temporal analysis. Identified hypospadias clusters with increasing trends in cases assessed (red) and clusters with decreasing trends (blue).

deaths in our country. ${ }^{15}$ The "Ten-Year Public Health Plan 2012-2021" (Plan Decenal de Salud Pública) includes the surveillance of birth defects as a fundamental element to guide actions aimed at reducing the morbidity and mortality of these conditions, preventing the consequences that represent a high cost for the family and the state. ${ }^{16}$ Although the notification of these birth defects has increased in recent years, there are still limitations regarding the registration of cases, mainly because data are based on births that occur in hospitals, without taking into account the percentage of births that occur in rural areas.

\section{Contrast with Literature}

During the last decade, the prevalence of hypospadias has remained constant in Colombia (6.8 per 10,000 newborns). ${ }^{3}$ International guidelines have suggested that the ideal age for hypospadias correction surgery is between 6 and 18 months old. ${ }^{17}$ The average age at the moment of surgery for hypospadias patients is 7.9 years old in Colombia. Its main reasons are lack of awareness of how to refer patients, delays on administrative processes during referral, and limited manpower of subspecialized pediatric urologists within the national territory. ${ }^{18}$ It is necessary to continue monitoring these patients to identify complications that may require reintervention in a timely manner as well as re-evaluating the psychological repercussions associated with this condition and long-term results of surgical interventions. ${ }^{19}$ In a health system with limited resources such as ours, these patients are not prioritized because this is not considered a life-threatening condition. ${ }^{20}$ Nonetheless, prompt surgical treatment prevents a secondary disability. Delaying it may increase the BoD. ${ }^{21,22}$ There are also indirect implications. At our system, having a patient with a congenital anomaly creates an economic burden to the family of the patients, since one of the guardians needs to stay at home and care for the child, reducing familial income and creating more limitations to healthcare access. ${ }^{18}$ A study conducted by Poenaru et $\mathrm{al}^{23}$ collected surgical records of 13 different congenital anomalies from a high-income setting (Canada) and a low-income country (Kenya). The objective was to calculate DALYs (Disability Adjusted Life Years) caused by delayed 
treatment, taking into account the weights of the disability as well as the ideal and real age of surgery. The results showed that delayed surgery were longer in Kenya for most of the procedures included in the analysis. The greatest delays were mainly in children with intestinal and urological conditions. Regarding hypospadias repair, African children had a greater delay in treatment when compared with Canadian children (50.0 months versus 17.2 months, $p<0.0001$ ), which translated into higher accumulated DALYS. Similar findings were reported by other groups, like that of Yousef et al., ${ }^{20}$ that reported surgical delays of 2.1 years for the treatment of the most common congenital anomalies, being the longest for hypospadias and cryptorchidism. These conditions are associated with significant disability weights and, therefore, are responsible for more than 75,000 DALYs. According to our results, cases presented in regions far from the center of the country may not be treated in a timely manner, which increases the burden of the disease and DALYS. Timely surgery avoids years of potential morbidity and reduces the risk of lifelong disability. DALYS increase with each year of treatment delay, and even surgical results may be worse as the age of the children increases for some congenital anomalies. $^{24}$

According to the Global Burden of Disease Study, 11\% of the global BoD is attributable to surgical conditions, including congenital malformations. ${ }^{25}$ Birth defects are a global health problem with limited access to surgical services, mainly in low- and middle-income countries (LMICs). ${ }^{26}$ Congenital abnormalities of the urinary tract represent a large proportion of these conditions. In Colombia, the incidence of genitourinary tract anomalies has been estimated as 43 per 100,000 live births. ${ }^{27}$ Based on this information, hypospadias is the most common congenital anomaly in the Colombian territory, and the lack of a well-distributed health system will pose a burden to the system if this and other congenital anomalies are not treated appropriately. The long-term implications should be taken into account, and efforts to improve subspecialized medical access need to be implemented. Although universal healthcare coverage is a highlight of the Colombian system, conditions like hypospadias need to be referred to and managed at highly specialized centers. A recent study conducted by Hanna et al. ${ }^{28}$ found that 7.1 million people $(\sim 15.1 \%$ of the population) in Colombia do not have timely healthcare access. The most affected populations are found in the Amazon and Orinoquia regions, which supports our results. If we consider that the prevalence rates of hypospadias remain stable, if not increasing, over time, there is hypothetically the possibility that roughly $87 \%$ of the patients with hypospadias will never be assessed by a subspecialist if the distribution of patient care is reflected based on our results.

\section{Limitations}

Among the limitations of the present study, it is important to mention the difficulty related to data reporting by the RIPS, such as the inadequate register of the cases. Additionally, we did not consider pediatric surgeons who also treat these patients. Despite this limitations, the present study offers an overview of the distribution of access to health services for patients with a pathology that can be disabling.

\section{Conclusion}

There is a greater concentration of cases evaluated in the center of the country, where the cities with better access to subspecialized medical care are located. This highlights inequalities in health services and the opportunity for surgical care among regions of the country. If we consider that the prevalence rates of hypospadias remain stable, $\sim 87 \%$ of patients with hypospadias will not be evaluated by a subspecialist.

\section{Consideraciones Éticas}

Se preservarán con exactitud los datos de los resultados obtenidos, en concordancia con los principios reconocidos científicamente. Los investigadores del estudio deben garantizar la protección de los datos recolectados. Se seguirá el artículo 1.6 de la declaración de Helsinki que determina: "Siempre debe respetarse el derecho del participante en la investigación de proteger su integridad y debe adoptarse todo clase de precauciones para resguardar la privacidad del individuo y para reducir al mínimo los efectos de la investigación sobre su integridad física y mental y sobre su personalidad".

Este estudio no conlleva ningún tipo de riesgo dado que no se realizarán intervenciones sobre el paciente. Para el desarrollo del estudio se tendrán en cuenta las consideraciones éticas descritas en el capítulo I, artículo 11 de la "investigación sin riesgo", en los que no se realiza ninguna intervención, contenido en la resolución $n^{\circ} 008430$ de 1993 del Ministerio de Salud y la Ley 84 de 1989.

The present study complies with the principles established in the Declaration of Helsinki. The authors declare that there are no conflicts of interest. This study is classified as a research study without risk, according to resolution 8430 of 1993, since it is part of the studies that use retrospective documentary research techniques and methods and those in which no intervention or intentional modification of the variables is carried out.

Conflict of Interests

The authors have no conflict of interests to declare.

\section{References}

1 van der Horst HJR, de Wall LL. Hypospadias, all there is to know. Eur J Pediatr 2017;176(04):435-441. Doi: 10.1007/s00431-0172864-5

2 Springer A, van den Heijkant M, Baumann S. Worldwide prevalence of hypospadias. J Pediatr Urol 2016;12(03):152.e1-152.e7. Doi: 10.1016/j.jpurol.2015.12.002

3 Fernández N, Pérez J, Monterrey P, et al. ECLAMC Study: Prevalence patterns of hypospadias in South America: Multi-national analysis over a 24-year period. Int Braz J Urol 2017;43(02): 325-334. Doi: 10.1590/s1677-5538.ibju.2016.0002

$4 \mathrm{Yu}$ X, Nassar N, Mastroiacovo P, et al. Hypospadias Prevalence and Trends in International Birth Defect Surveillance Systems, 19802010. Eur Urol 2019;76(04):482-490. Doi: 10.1016/j.eururo. 2019.06.027

5 Zarante I, Franco L, López C, Fernández N. [Frequencies of congenital malformations: assessment and prognosis of 52,744 births in three cities of Colombia]. Biomedica 2010;30(01): 65-71. Doi: 10.7705/biomedica.v30i1 
6 Baskin LS, Ebbers MB. Hypospadias: anatomy, etiology, and technique. J Pediatr Surg 2006;41(03):463-472. Doi: 10.1016/j. jpedsurg.2005.11.059

7 Carmichael SL, Shaw GM, Laurent C, Croughan MS, Olney RS, Lammer EJ. Maternal progestin intake and risk of hypospadias. Arch Pediatr Adolesc Med 2005;159(10):957-962. Doi: 10.1001/ archpedi.159.10.957

8 Brouwers MM, Feitz WFJ, Roelofs LAJ, Kiemeney LALM, de Gier RPE, Roeleveld N. Risk factors for hypospadias. Eur J Pediatr 2007; 166(07):671-678. Doi: 10.1007/s00431-006-0304-Z

9 Poenaru D, Pemberton J, Frankfurter C, Cameron BH, Stolk E. Establishing disability weights for congenital pediatric surgical conditions: a multi-modal approach. Popul Health Metr 2017;15 (01):8. Doi: 10.1186/s12963-017-0125-5

10 Örtqvist L, Andersson M, Strandqvist A, et al. Psychosocial outcome in adult men born with hypospadias. J Pediatr Urol 2017;13 (01):79.e1-79.e7. Doi: 10.1016/j.jpurol.2016.08.008

11 Springer A. Assessment of outcome in hypospadias surgery - a review. Front Pediatr 2014;2:2. Doi: 10.3389/fped.2014.00002

12 Aulagne MB, Harper L, de Napoli-Cocci S, Bondonny JM, Dobremez E. Long-term outcome of severe hypospadias. J Pediatr Urol 2010; 6(05):469-472. Doi: 10.1016/j.jpurol.2009.12.005

13 Schlomer B, Breyer B, Copp H, Baskin L, DiSandro M. Do adult men with untreated hypospadias have adverse outcomes? A pilot study using a social media advertised survey. J Pediatr Urol 2014;10(04):672-679. Doi: 10.1016/j.jpurol.2014.01.024

14 Van Batavia JP, Shukla AR, Joshi RS, Reddy PP. Pediatric Urology and Global Health: Why Now and How to Build a Successful Global Outreach Program. Urol Clin North Am 2018;45(04): 623-631. Doi: 10.1016/j.ucl.2018.06.009

15 Departamento Administrativo Nacional de Estadística (DANE) Cuadro 5. Defunciones por grupos de edad y sexo, según departamento, municipio de residencia y grupos de causas de defunción (lista de causas agrupadas 6/67 CIE-10 de OPS. https://www. dane.gov.co/index.php/estadisticas-por-tema/salud/nacimientos-y-defunciones/defunciones-no-fetales/defunciones-nofetales-2017. Published 2017

16 Greace Alejandra Avila Mellizo. INFORME DE EVENTO DEFECTOS CONGÉNITOS, COLOMBIA, SEMESTRE I 2019. https://www.ins. gov.co/buscador-eventos/Informesdeevento/DEFECTOSCONGÉNITOSSEMESTREI2019.pdf. Published 2019

17 Radmayr C, Bogaert G, Dogan HS, Nijman JM, Silay MS, . R. Stein ST. Paediatric Urology. EAU Guidel Edn Present EAU Annu Congr Amsterdam 2020 ISBN 978-94-92671-07-3. https://uroweb.org/guideline/paediatric-urology/\#note_258

18 Fernandez N, Puerto AP, Arreaza D, et al. Social and Clinical Impact of Congenital Urological Malformations in a Developing Country:
The Need for a TransdisciplinaryWay of Treatment. Urol Colomb 2019;28(04):285-290. Doi: 10.1055/s-0038-1668110

19 Wiener JS, Huck N, Blais A-S, et al. Challenges in pediatric urologic practice: a lifelong view. World J Urol 2020. Doi: 10.1007/s00345020-03203-1

20 Yousef Y, Lee A, Ayele F, Poenaru D. Delayed access to care and unmet burden of pediatric surgical disease in resource-constrained African countries. J Pediatr Surg 2019;54(04):845-853. Doi: $10.1016 /$ j.jpedsurg.2018.06.018

21 Smith ER, Concepcion TL, Shrime M, et al; Global Initiative for Children's Surgery. Waiting Too Long: The Contribution of Delayed Surgical Access to Pediatric Disease Burden in Somaliland. World J Surg 2020;44(03):656-664. Doi: 10.1007/s00268019-05239-w

22 Concepcion TL, Dahir S, Mohamed M, et al; Global Initiative for Children's Surgery. Barriers to Surgical Care Among Children in Somaliland: An Application of the Three Delays Framework. World J Surg 2020;44(06):1712-1718. Doi: 10.1007/s00268020-05414-4

23 Poenaru D, Pemberton J, Cameron BH. The burden of waiting: DALYs accrued from delayed access to pediatric surgery in Kenya and Canada. J Pediatr Surg 2015;50(05):765-770. Doi: 10.1016/j. jpedsurg.2015.02.033

24 Ozgediz D, Poenaru D. The burden of pediatric surgical conditions in low and middle income countries: a call to action. J Pediatr Surg 2012;47(12):2305-2311. Doi: 10.1016/j.jpedsurg. 2012.09.030

25 Global Burden of Disease Study 2013 Collaborators. Global, regional, and national incidence, prevalence, and years lived with disability for 301 acute and chronic diseases and injuries in 188 countries, 1990-2013: a systematic analysis for the Global Burden of Disease Study 2013. Lancet 2015;386(9995):743-800. Doi: 10.1016/S0140- 6736(15)60692-4

26 Bickler SW, Spiegel D. Improving surgical care in low- and middleincome countries: a pivotal role for the World Health Organization. World J Surg 2010;34(03):386-390. Doi: 10.1007/s00268009-0273-2

27 Fernández N, Henao-Mejía J, Monterrey P, Pérez J, Zarante I. Association between maternal prenatal vitamin use and congenital abnormalities of the genitourinary tract in a developing country. J Pediatr Urol 2012;8(02):121-126. Doi: 10.1016/j. jpurol.2011.07.005

28 Hanna JS, Herrera-Almario GE, Pinilla-Roncancio M, et al. Use of the six core surgical indicators from the Lancet Commission on Global Surgery in Colombia: a situational analysis. Lancet Glob Health 2020;8(05):e699-e710. Doi: 10.1016/S2214-109X(20) 30090-5 